\title{
The off-design modelling of a combined-cycle power plant
}

\author{
Rushavya Naidu, ${ }^{1, *}$, and Wim Fuls ${ }^{2}$ \\ ${ }^{1}$ ATProM Research Unit, University of Cape Town, Cape Town, South Africa \\ ${ }^{2}$ Department of Mechanical Engineering, University of Cape Town, Cape Town, South Africa
}

\begin{abstract}
The objective of this project was to develop a model of a combined-cycle power plant in Flownex which can be solved in off-design conditions in order to compare it to plant data. The verification of this model will show that Flownex can be used to effectively and efficiently model a combined-cycle power plant. The process of development of the final Flownex model was achieved using various additional software. Initially, an analytical model was developed in Mathcad (software used for engineering calculations). Thereafter, a model was built in Virtual Plant, a thermodynamic modelling software for assessing plant performance. Finally, the Flownex model was designed. For the single, double, and triple pressure combined-cycle power plant systems, the analytical, Virtual Plant and Flownex models were compared. The results of all the models agreed closely with one another. The triple-pressure design and off-design Virtual Plant and Flownex models were also compared to plant data and it was concluded that Flownex was successful in modelling the design and offdesign conditions of a combined-cycle power plant.
\end{abstract}

\section{List of Nomenclature}

Table 1. General Symbols.

\begin{tabular}{|l|l|}
\hline$h$ & Enthalpy $(\mathrm{kJ} / \mathrm{kg})$ \\
\hline$\dot{m}$ & Mass flow rate $(\mathrm{kg} / \mathrm{s})$ \\
\hline$Q$ & Heat transfer $(\mathrm{W})$ \\
\hline$T$ & Temperature $\left({ }^{\circ} \mathrm{C}\right)$ \\
\hline$\Delta T_{l m}$ & $\begin{array}{l}\text { Log mean temperature difference } \\
(\mathrm{K})\end{array}$ \\
\hline$U A$ & Overall conductance $(\mathrm{W} / \mathrm{K})$ \\
\hline \multicolumn{2}{|c|}{ Subscripts } \\
\hline$e c$ & Economiser \\
\hline$e v$ & Evaporator \\
\hline$g$ & Gas phase \\
\hline $\begin{array}{l}g 1, g 2, \\
g 3 \ldots\end{array}$ & Gas properties at points of the HRSG \\
\hline
\end{tabular}

* Rushavya Naidu : rushavyan@gmail.com 


\begin{tabular}{|l|l|}
\hline$s$ & Water/steam phase \\
\hline$s h$ & Superheater \\
\hline$s o$ & Steam exiting superheater \\
\hline$v$ & Saturated steam \\
\hline$w 1$ & Water entering economiser \\
\hline$w 2$ & Water exiting economiser \\
\hline
\end{tabular}

Table 2. Acronyms and Abbreviations.

\begin{tabular}{|l|l|}
\hline$E C O N$ & Economiser \\
\hline$E V A P$ & Evaporator \\
\hline$H P$ & High pressure \\
\hline$H R S G$ & $\begin{array}{l}\text { Heat Recovery Steam Genera- } \\
\text { tor }\end{array}$ \\
\hline$H T$ & High temperature \\
\hline$I P$ & Intermediate pressure \\
\hline$I T$ & Intermediate temperature \\
\hline$L P$ & Low pressure \\
\hline$L T$ & Low temperature \\
\hline$N T U$ & Number of transfer units \\
\hline$R H$ & Reheater \\
\hline$S H$ & Superheater \\
\hline
\end{tabular}

\section{Introduction}

Renewable energy presents itself as a solution to the downfalls of fossil fuels, however, these resources are only able to account for less than $10 \%$ of the world's total energy demand [1]. Unfortunately, this statistic is not expected to change significantly in the near future. As a result of this, and in order to ensure the conservation of fossil fuels, the increase of efficiency in present power generation systems is critical. Combined-cycle power plants have the highest efficiency in the world in comparison to other power plants that operate on power grids, being between $45 \%$ and $57 \%$ [2].

These plants consist of a gas turbine as the topping cycle, forming the core of the plant, and a Rankine cycle with a steam turbine as the bottoming cycle [2]. A component called the Heat Recovery Steam Generator (HRSG) forms a connection point between the two cycles. It uses the heat released from the gas turbine to produce high pressure and temperature steam to be sent to the steam turbine. The schematic of a combined-cycle power plant is shown in Figure 1.

The objective of this project was to develop a model of a combined-cycle power plant in Flownex which can be solved in off-design conditions in order to compare it to results from other software as well as plant data. The verification of this model will show that Flownex can be used to effectively and efficiently model a combined-cycle power plant. 


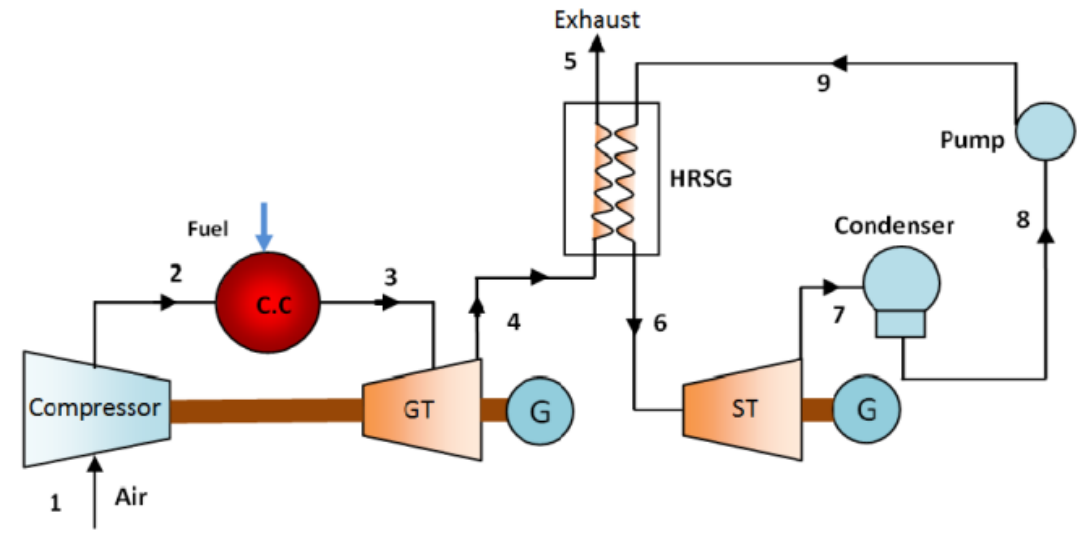

Fig. 1. Basic Combined-Cycle Power Plant [3].

\section{Heat Recovery Steam Generator}

The HRSG acts as a heat exchanger which uses exhaust gases from the gas turbine to generate steam. When designing an HRSG, the evaluation of steam generation and steam temperature profiles are important starting points [4]. The steam production and gas and steam temperature profiles are dependent on the assumed pinch point and approach point values. Therefore, HRSG's can be thermally designed without having to physically size them [5]. A basic single pressure HRSG is composed of an economiser, evaporator and superheater. The components work together to convert thermal energy from the exhaust gas into steam. Feedwater is heated in the economiser after which it enters the drum at slightly subcooled conditions. The water then circulates in the evaporator, re-entering the drum as a water/steam mixture [6]. The water and steam separate in the drum and the saturated steam travels to the superheater where it experiences the maximum heat exchange temperature (inlet temperature of the exhaust gas from the gas turbine) and is superheated to the desired temperature.

\section{Previous Work}

There are numerous models of combined-cycle power plants that have been developed previously. This paper is based mainly on the works of V. Ganapathy [5] and Alobaid et al. [7]. Ganapathy developed a program for HRSG simulation in order to produce the thermal design and off-design performance of unfired, fired, simple or complex, multimodule, multipressure gas turbine HRSGs without having to physically size them [5].

Alobaid et al. presented a comparative study of different dynamic process simulation codes for combined-cycle power plants at design and off-design conditions [7]. A combinedcycle power plant utilising a sub-critical triple-pressure HRSG was developed using Aspen Plus Dynamics and Apros. These models were validated against plant data at $100 \%, 80 \%$ and $60 \%$ load.

Tică et al. developed a combined-cycle power plant for optimisation [8]. The model was developed using Dymola/Modelica, with the use of ThermoPower which is a library for modelling thermal power plants, and the components were validated by experimental data.

Rauch et al. developed a model in Matlab which determined the maximum thermal efficiency of a combined-cycle power plant limited by gas temperature entering and exiting the gas turbine, condenser temperature and the dryness fraction at the outlet of the steam turbine [9]. 
Srinivas et al. used computer simulation software to assess the performance of a combined-cycle power plant at part loads [10]. The study presented the optimum process parameters of steam exiting the HRSG at part loads.

\section{Methodology}

\subsection{Single Pressure - Analytical}

First, a single pressure system was analysed and modelled in the design mode. Figure 2 provides a schematic of the system. The design values used for this model were obtained from a textbook written by V. Ganapathy [11]. The architecture and inputs used for the model were therefore based on that of the textbook.

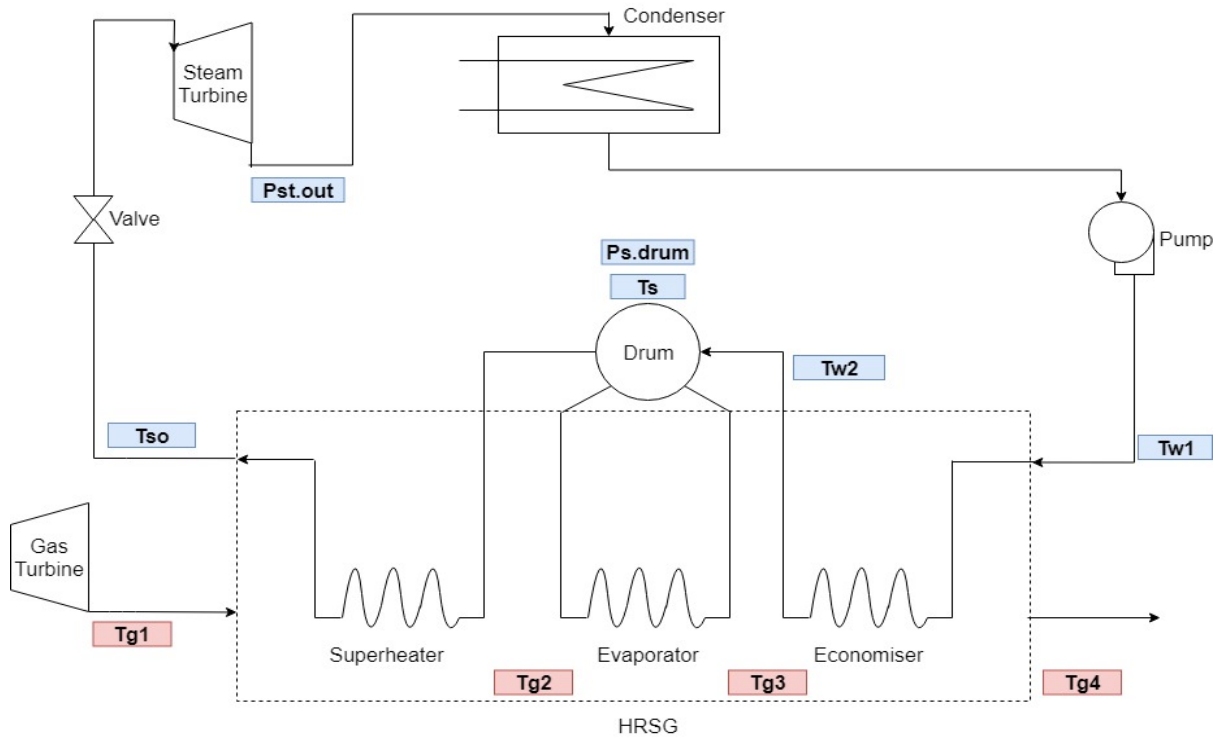

Fig. 2. Schematic of a single-pressure combined-cycle power plant.

A temperature profile of both the gas and water/steam in the HRSG was developed so that the duties of each component could be calculated and the foundation of the HRSG could be established.

The known values for the system were the exhaust gas mass flow and temperature, desired pressure of the water/steam in the HRSG, temperature of the feedwater into the HRSG and the desired temperature of steam to be generated.

Assumptions for the pinch and approach points were made $\left(8.3^{\circ} \mathrm{C}\right.$ each $)$ in order to form the basis of the HRSG design. Energy balance equations were used to evaluate the system which is shown in equation (1).

$$
Q=\dot{m} \times \Delta h
$$

The overall conductance (UA) of each component was calculated using equation (2) in order for the system to be evaluated in the off-design model.

$$
U A=\frac{Q}{\Delta T_{l m}}
$$

Finally, the pressure drop over the steam turbine was calculated. The feedwater temperature was used to find the condenser pressure. This was for simplicity reasons and led to a high condenser temperature and pressure. This did not decrease the accuracy of the model as it was just for example sake. 
The effectiveness-NTU method was used to model the off-design case. Equation (3) was used to calculate the off-design UA.

$$
U A_{\text {off }}=U A_{\text {design }}\left(\frac{\dot{m}_{\text {g.off }}}{\dot{m}_{\text {g.design }}}\right)^{0,65}
$$

Initial assumptions had to be made for the steam mass flow rate, steam pressure and the temperature of water exiting the economiser $\left(T_{w 2}\right)$. The flow coefficient was used to calculate the pressure of steam entering the turbine at low loads, this allows for turbine swallowing capacity to be maintained. The actual steam pressure in the HRSG (calculated using the flow coefficient) was used to iterate the initial assumption. Iterations were simultaneously done for the steam mass flow rate and $T_{w 2}$.

\subsection{Single Pressure - Virtual Plant}

A model was then created in Virtual Plant in order to predict and assess the performance of the plant. The Virtual Plant model cannot be built without the analytical model as a basis, since it provides process conditions around each component which is required by Virtual Plant. This model served as a verification step to ensure that the analytical model was running correctly.

For the off-design model, the load was decreased by decreasing the gas mass flow accordingly. Other factors such as UA and steam pressure at each low load were automatically calculated by Virtual Plant.

\subsection{Single Pressure - Flownex}

The single pressure model developed in Flownex is shown in Figure 3. The condenser and feedwater pump are omitted from this model because creating a closed cycle in Flownex would lead to additional complications. The upper path shows the flow of gas and the lower one shows that of water/steam. Boundary conditions were used to set the temperature and pressure at the beginning of each stream. For gas, the boundary condition at the beginning of the stream was also used to set the 'Mass Source Fraction' which defines the gas composition and the one at the end of the stream set the mass flow rate. For steam, the boundary condition at the end of the stream was set as outlet pressure of the turbine. This was done to create a fixed condenser pressure.

Flow Resistance elements were used to connect all components together. These were set to a high flow admittance in order for the pressure drop across them to be negligible as it was not being modelled.

The economiser and superheater were modelled using Primary and Secondary Heat Exchanger components which allow for the UA as an input. Coefficients for pressure drop were also required as an input, which were minimised to allow for pressure drop to be negligible. Flownex uses the effectiveness-NTU method to calculate heat transfer in these elements.

The evaporator could not be modelled using a Heat Exchanger component due to the phase change that takes place in an evaporator. It had to be manually modelled as Flow Resistances connected in a loop to a drum, where a Composite Heat Transfer Element transfers heat from the gas to one of the Flow Resistance elements in the loop. The drum was modelled using a two-phase tank which allows for phase separation of a two-phase fluid. A boundary condition was used for the drum setting the quality to 0.2 . This ensures that there is always at least some water in the drum. 


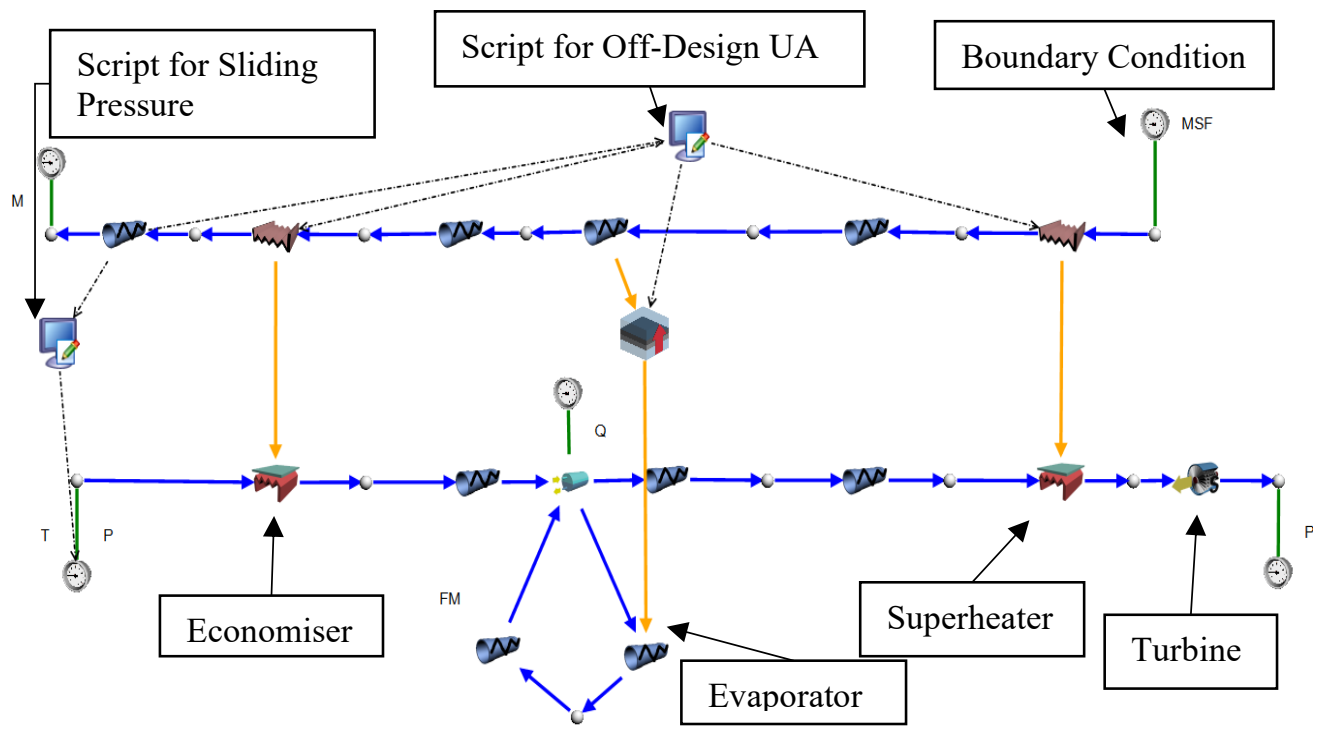

Fig. 3. Single pressure Flownex model.

A Simple Turbine was used to model the turbine. The empirical loss coefficient option was chosen for the off-design pressure calculations.

In order to find the operational pressure at each low load, the water/steam pressure was manually adjusted until the energy source of the drum became zero. If all constraints cannot be met, an external heat source or sink must be utilised. Therefore, in order to ensure that the quality boundary condition was met without external factors, the water/steam pressure was adjusted to eliminate the energy source.

Two scripts were added to account for off-design modelling. The first script dealt with the off-design UA. It used the gas mass flow through the Flow Resistance, as an input for off-design gas mass flow, to calculate the off-design UA for each component (using equation (3)). These results were then used to control the UA in the economiser and superheater and the convective heat transfer coefficient in the evaporator.

The second script controlled the sliding pressure on the steam side. It extracted the mass flow rate of gas through the Flow Resistance to control the pressure input at the Boundary Condition for water/steam. In order to achieve this, the model was run at various loads to find the operational pressure at each low load by manually adjusting the pressure until the energy source of the drum was zero. The operational pressures were then plotted against the gas mass flow at each load. The trend was linear so the equation for the trendline was used in the script to obtain water/steam pressure from gas mass flow.

\subsection{Double Pressure}

A double pressure model meant the addition of another drum. The model is therefore made up of a low-pressure system and a high-pressure system. In this model, the low-pressure system was composed of an economiser and evaporator only and the high-pressure system was composed of an economiser, evaporator and superheater. The approach of the analytical, Virtual Plant and Flownex models were similar to that of the single pressure. 


\subsection{Triple Pressure - Analytical}

This model was based on that of Alobaid et al [7]. The approach to modelling the triple pressure system was different to the single and double pressure systems. Firstly, the gas flow path no longer flowed through the pressure levels from high- to low-pressure consecutively. Secondly, this model contained a reheating $(\mathrm{RH})$ section following the intermediate-pressure section. Also, it included multiple economisers and superheaters in the high-pressure section, as well as locations where the gas would split through different heat exchangers that were at the same gas path location.

The schematic in Figure 4 shows the layout of the model with the initial known temperatures of water/steam represented by green circles.

Certain assumptions made in this model were critical. These included the pinch point of each pressure level (3), the ratio of the 2 gas splits in the parallel components and 2 water temperatures that had to be assumed. These 7 values had to be fine-tuned in the highly optimised system until there was no steaming or temperature cross situations in the system.

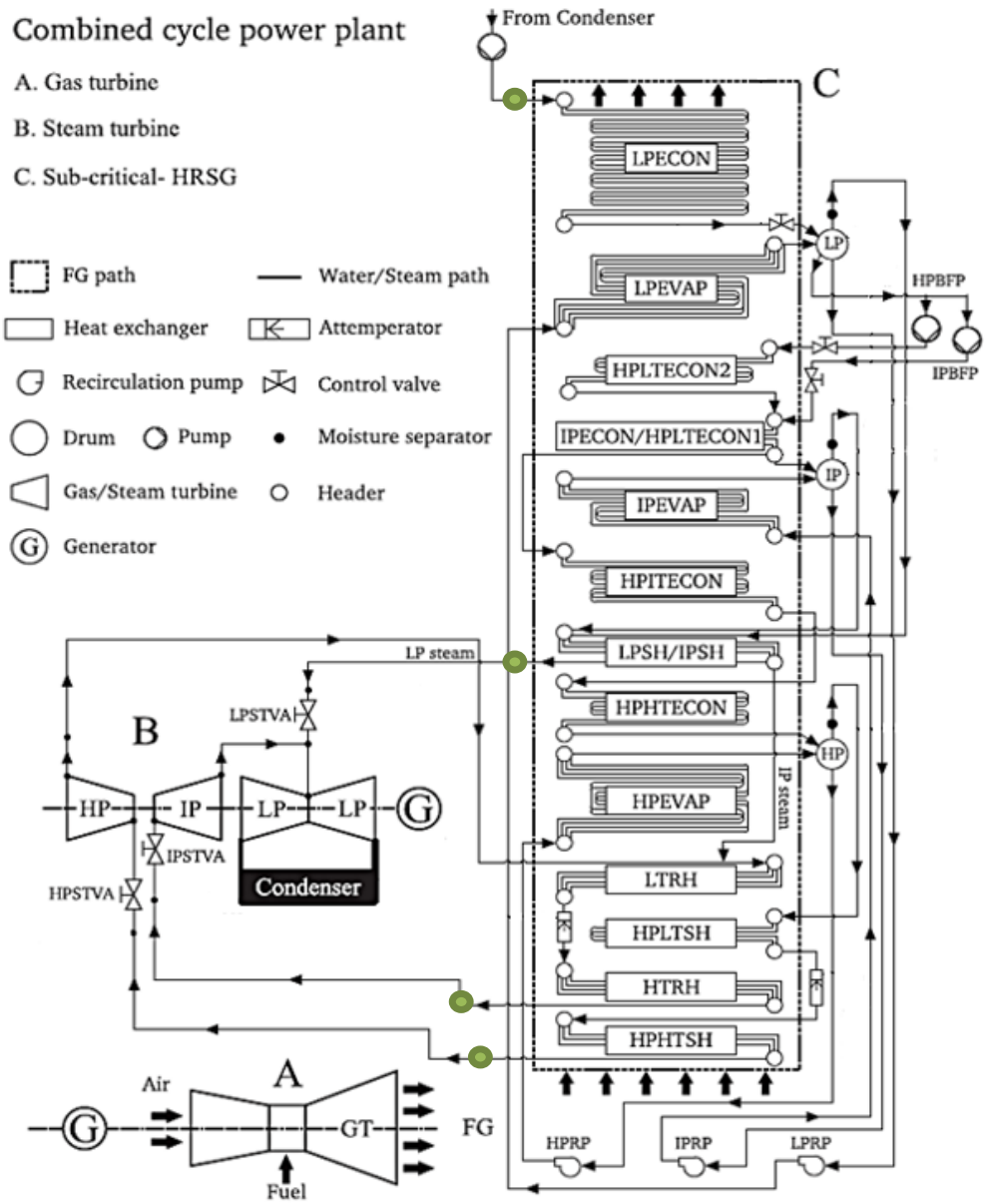

Fig. 4. Schematic of triple-pressure model [7]. 


\subsection{Triple Pressure - Flownex}

The triple pressure Flownex model is shown in Figure 5. Due to the complexity of the model, it was separated onto 3 drawing pages and interconnected using projected nodes called View Nodes.

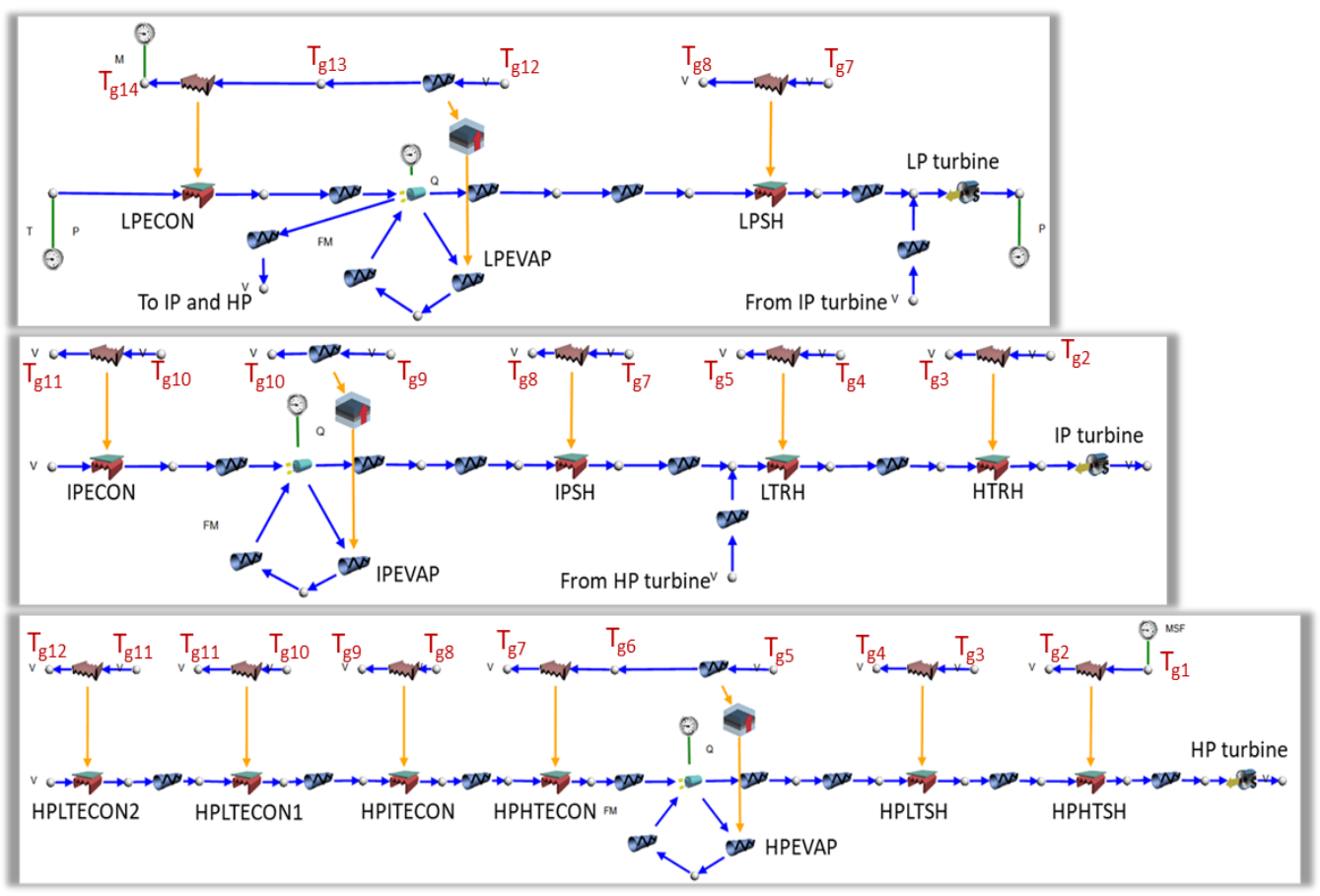

Fig. 5. Triple pressure Flownex model.

The modelling of the economisers, evaporators and superheaters were similar to that of the single and double pressure models.

For the off-design model, the input low-pressure value and both pump heads had to be manually adjusted until all three drums had an energy source close to zero, without causing any steaming in the economisers. Only two low load conditions were analysed $(60 \%$ and $80 \%$ ) as these were the only low loads at which information was available from Alobaid et al [7].

It was not feasible to solve for an off-design analytical model of the triple pressure system due to its complexity. Therefore, the triple pressure off-design Flownex model was verified using the triple pressure Virtual Plant model.

\section{Results}

The triple pressure model was analysed in design and off-design mode. The design case was analysed using a comparison between each model. The design and off-design cases were then analysed by comparing results of the Virtual Plant and Flownex models to published plant data obtained from Alobaid et al [7]. 


\subsection{Design Model}

The comparisons between plant data and the analytical results for steam are shown in Table 3.

Table 3. Comparison between design base plant data and analytical results for steam.

\begin{tabular}{|c|c|c|c|c|c|c|c|c|c|c|}
\hline $\begin{array}{c}\text { Com- } \\
\text { ponent }\end{array}$ & \multicolumn{3}{|c|}{ Steam mass flow (kg/s) } & \multicolumn{3}{|c|}{ Outlet temp. $\left({ }^{\circ} \mathrm{C}\right)$} & \multicolumn{3}{|c|}{ Pressure (bar) } \\
\hline $\begin{array}{c}\text { Ana- } \\
\text { lytical }\end{array}$ & $\begin{array}{c}\text { Error } \\
\%\end{array}$ & Plant & $\begin{array}{c}\text { Ana- } \\
\text { lytical }\end{array}$ & $\begin{array}{c}\text { Error } \\
\%\end{array}$ & Plant & $\begin{array}{c}\text { Ana- } \\
\text { lytical }\end{array}$ & $\begin{array}{c}\text { Error } \\
\%\end{array}$ \\
\hline $\begin{array}{c}\text { outlet } \\
\text { RH } \\
\text { outlet }\end{array}$ & 78.2 & 78.2 & 0 & 567 & 567 & 0 & 97.7 & 97.7 & 0 \\
\hline $\begin{array}{c}\text { LPSH } \\
\text { outlet }\end{array}$ & 9.8 & 83.2 & 0 & 567 & 567 & 0 & 21.4 & 21.4 & 0 \\
\hline
\end{tabular}

The comparisons between plant data and the analytical results for gas variables are shown in Table 4.

Table 4. Comparisons between design base plant data and analytical results for gas.

\begin{tabular}{|c|c|c|c|}
\hline Gas Variable & Plant & Analytical & Error \% \\
\hline Mass flow $(\mathrm{kg} / \mathrm{s})$ & 587 & 587 & 0 \\
\hline $\operatorname{Tg} 1-$ Inlet $\left({ }^{\circ} \mathrm{C}\right)$ & 628 & 624.8 & 0.51 \\
\hline $\operatorname{Tg} 14-$ Outlet $\left({ }^{\circ} \mathrm{C}\right)$ & 81 & 100.7 & -24.32 \\
\hline
\end{tabular}

The low-, intermediate- and high-pressure levels were plotted separately for the triple pressure models. The low-pressure water/steam and gas temperature profiles for each model is shown in Figure 6. The upper line represents the gas flow and the lower one represents the flow of water/steam. The break in the gas flow line signifies the omittance of components from other pressure levels.

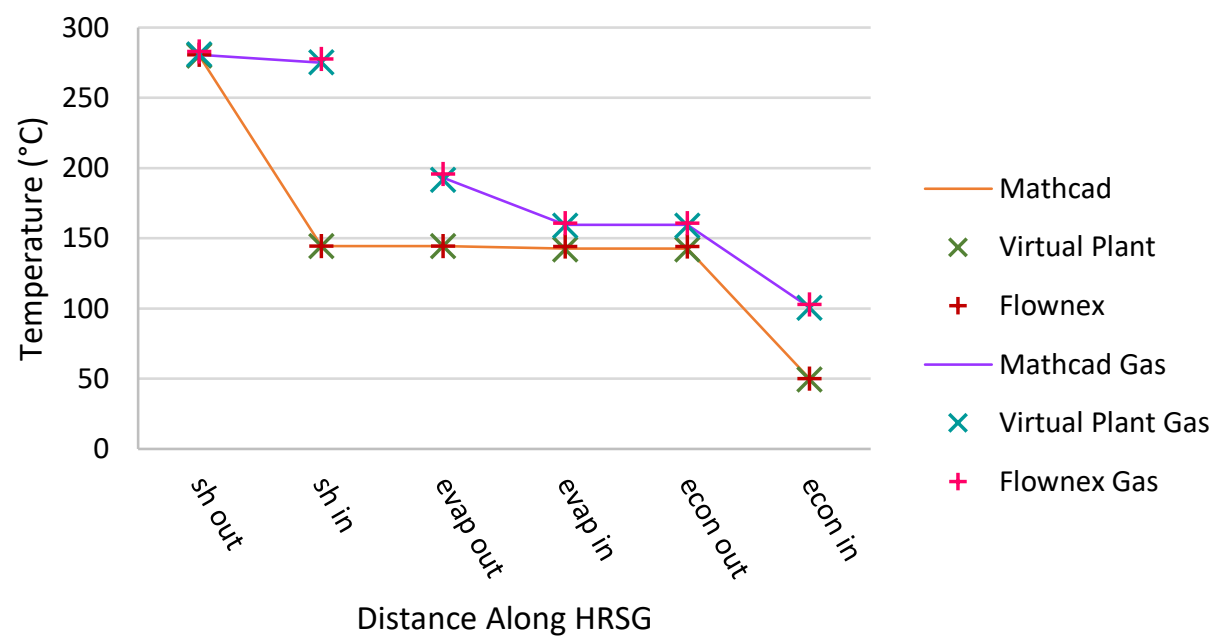

Fig. 6. Graph showing comparison of triple pressure models (low-pressure). 
The intermediate-pressure water/steam and gas temperature profiles for each model is shown in Figure 7.

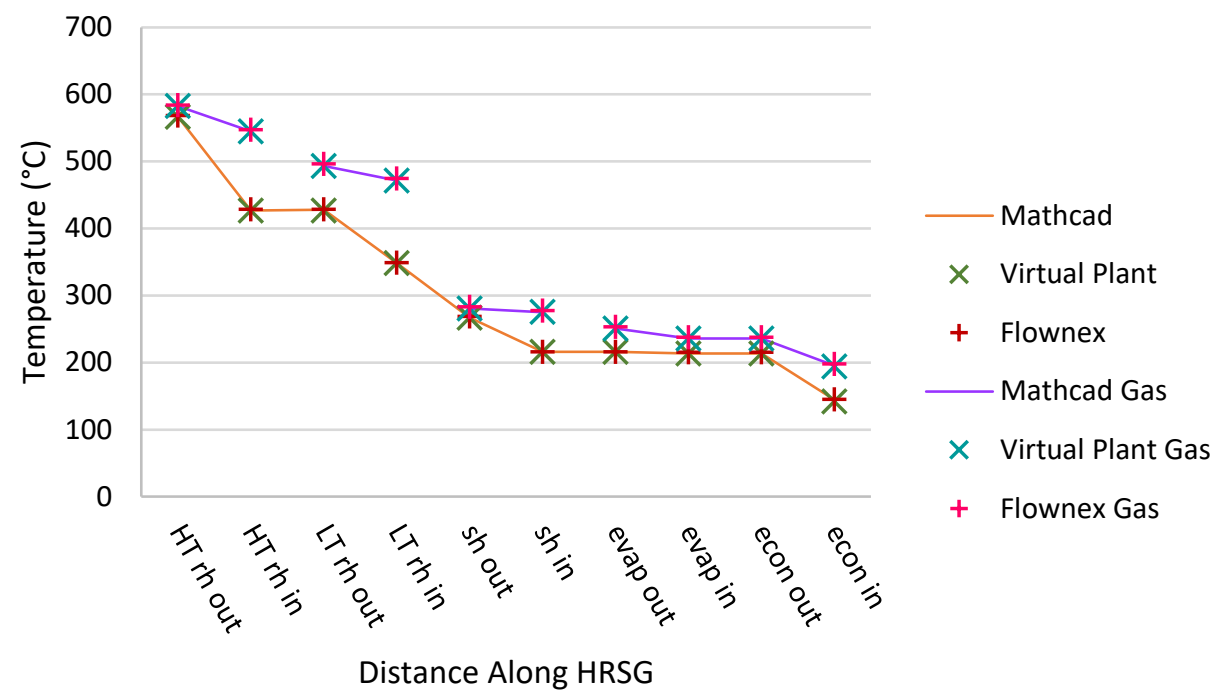

Fig. 7. Graph showing comparison of triple pressure models (intermediate-pressure).

The high-pressure water/steam and gas temperature profiles for each model is shown in Figure 8.

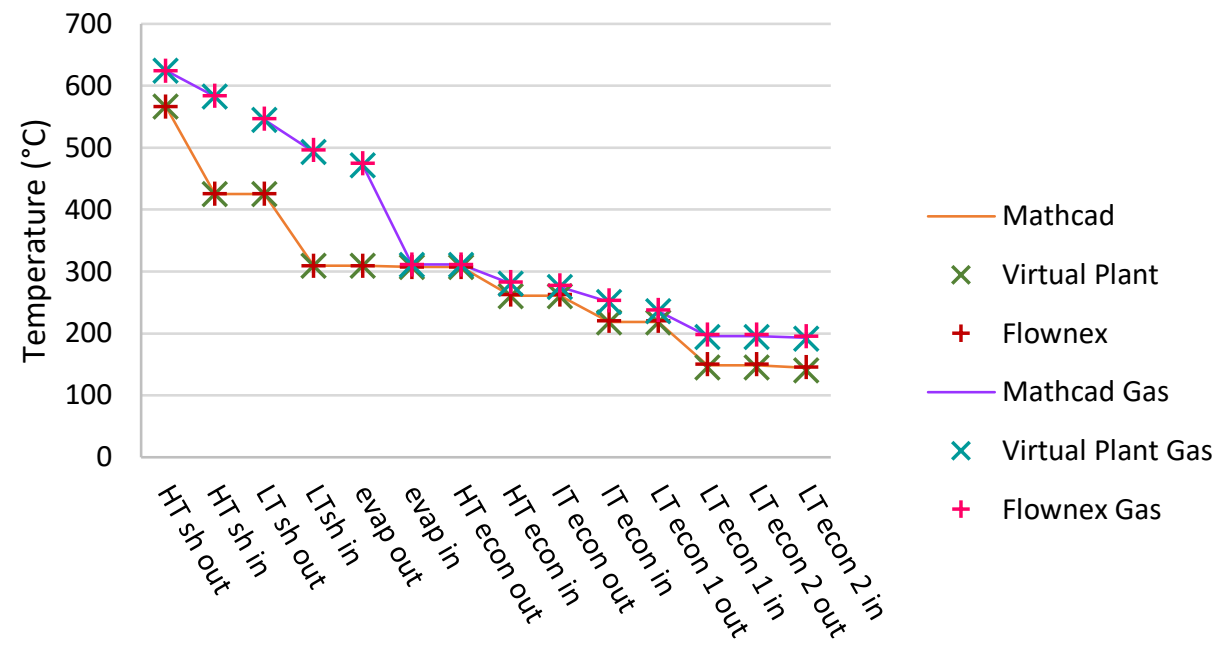

Distance Along HRSG

Fig. 8. Graph showing comparison of triple pressure models (high-pressure).

Despite the fact that numerous assumptions had to be made for the triple pressure system, the results agree quite closely with one another. Considering the complexity of the system and the fact that a small difference at one point of the system could cause a larger difference down the line, the models produced successful results. 


\subsection{Off-Design Model}

The results available from Alobaid et al. were the mass flow rate, temperature and pressure of the exiting steam for each pressure level i.e. the outlet of the HPHTSH, HTRH and LPSH [7]. Results for the outlet of the HPHTSH are shown in Table 5 with 'Expected' representing published plant data.

Table 5. Triple pressure off-design comparisons for HPHTSH outlet.

\begin{tabular}{|c|c|c|c|c|c|c|c|c|c|}
\hline \multirow[b]{2}{*}{$\begin{array}{c}\text { Load } \\
\%\end{array}$} & \multicolumn{3}{|c|}{$\begin{array}{l}\text { HPHTSH steam mass } \\
\text { flow }(\mathrm{kg} / \mathrm{s})\end{array}$} & \multicolumn{3}{|c|}{$\begin{array}{l}\text { HPHTSH outlet temp. } \\
\left({ }^{\circ} \mathrm{C}\right)\end{array}$} & \multicolumn{3}{|c|}{ HPHTSH pressure (bar) } \\
\hline & $\begin{array}{c}\text { Ex- } \\
\text { pected }\end{array}$ & $\begin{array}{l}\text { Vir- } \\
\text { tual } \\
\text { Plant }\end{array}$ & $\begin{array}{c}\text { Flown } \\
\text { ex }\end{array}$ & $\begin{array}{c}\text { Ex- } \\
\text { pected }\end{array}$ & $\begin{array}{l}\text { Vir- } \\
\text { tual } \\
\text { Plant }\end{array}$ & $\begin{array}{c}\text { Flown } \\
\text { ex }\end{array}$ & $\begin{array}{c}\text { Ex- } \\
\text { pected }\end{array}$ & $\begin{array}{c}\text { Vir- } \\
\text { tual } \\
\text { Plant }\end{array}$ & $\begin{array}{l}\text { Flown } \\
\text { ex }\end{array}$ \\
\hline 80 & 66.9 & 65.6 & 67.3 & 566.8 & 576.4 & 572.5 & 88 & 82.9 & 84.7 \\
\hline 60 & 58.3 & 56.3 & 57.8 & 566.9 & 583.2 & 579.4 & 76.2 & 71.7 & 73.3 \\
\hline
\end{tabular}

Results for the outlet of the HTRH are shown in Table 6.

Table 6. Triple pressure off-design comparisons for HTRH outlet.

\begin{tabular}{|c|c|c|c|c|c|c|c|c|c|}
\hline \multirow[b]{2}{*}{$\begin{array}{c}\text { Load } \\
\%\end{array}$} & \multicolumn{3}{|c|}{$\begin{array}{l}\text { HTRH steam mass flow } \\
(\mathrm{kg} / \mathrm{s})\end{array}$} & \multicolumn{3}{|c|}{ HTRH outlet temp. $\left({ }^{\circ} \mathrm{C}\right)$} & \multicolumn{3}{|c|}{ HTRH pressure (bar) } \\
\hline & $\begin{array}{c}\text { Ex- } \\
\text { pected }\end{array}$ & $\begin{array}{l}\text { Vir- } \\
\text { tual } \\
\text { Plant }\end{array}$ & $\begin{array}{c}\text { Flown } \\
\text { ex }\end{array}$ & $\begin{array}{c}\text { Ex- } \\
\text { pected }\end{array}$ & $\begin{array}{l}\text { Vir- } \\
\text { tual } \\
\text { Plant }\end{array}$ & $\begin{array}{c}\text { Flown } \\
\text { ex }\end{array}$ & $\begin{array}{c}\text { Ex- } \\
\text { pected }\end{array}$ & $\begin{array}{c}\text { Vir- } \\
\text { tual } \\
\text { Plant }\end{array}$ & $\begin{array}{c}\text { Flown } \\
\text { ex }\end{array}$ \\
\hline 80 & 74.7 & 69.7 & 71.6 & 567 & 571.3 & 569.4 & 20.6 & 18 & 18.5 \\
\hline 60 & 64.9 & 59.8 & 61.6 & 566.9 & 574.5 & 572.4 & 17.7 & 15.5 & 15.9 \\
\hline
\end{tabular}

Results for the outlet of the LPSH are shown in Table 7. The design outlet steam temperature had to be decreased from $293^{\circ} \mathrm{C}$ to $280^{\circ} \mathrm{C}$, therefore, a considerable difference in these results were expected.

Table 7. Triple pressure off-design comparisons for LPSH outlet.

\begin{tabular}{|c|c|c|c|c|c|c|c|c|c|}
\hline \multirow{2}{*}{$\begin{array}{c}\text { Load } \\
\%\end{array}$} & \multicolumn{3}{|c|}{$\begin{array}{c}\text { LPSH steam mass flow } \\
(\mathrm{kg} / \mathrm{s})\end{array}$} & \multicolumn{3}{|c|}{ LPSH outlet temp. $\left({ }^{\circ} \mathrm{C}\right)$} & \multicolumn{3}{|c|}{ LPSH pressure (bar) } \\
& $\begin{array}{c}\text { Ex- } \\
\text { pected }\end{array}$ & $\begin{array}{c}\text { Vir- } \\
\text { tual }\end{array}$ & $\begin{array}{c}\text { Flown } \\
\text { Plant }\end{array}$ & $\begin{array}{c}\text { Ex } \\
\text { pected }\end{array}$ & $\begin{array}{c}\text { Vir- } \\
\text { tual }\end{array}$ & $\begin{array}{c}\text { Flown } \\
\text { Plant }\end{array}$ & $\begin{array}{c}\text { Ex- } \\
\text { pected }\end{array}$ & $\begin{array}{c}\text { Vir- } \\
\text { tual }\end{array}$ & $\begin{array}{c}\text { Flown } \\
\text { ex }\end{array}$ \\
\hline 80 & 7.7 & 7.7 & 8.1 & 289.9 & 271.4 & 271 & 3.9 & 3.4 & 3.5 \\
\hline 60 & 6.4 & 6.4 & 6.8 & 281 & 264 & 263.3 & 3.3 & 2.9 & 3 \\
\hline
\end{tabular}

\section{Discussion}

For the low-pressure steam outlet, there was a larger error in outlet temperature due to the temperature change that had to be made at this point to avoid a temperature cross situation. Additionally, the error in temperature for all pressure levels at low load is expected due to the absence of attemperation in the Flownex and Virtual Plant models as this was not modelled for. These variations meant that the Flownex and Virtual Plant models would behave differently to the plant under off-design conditions. There was also the possibility of 
various other control mechanisms, such as supplementary firing; control valves; moisture separators; and bypass controls, used in the plant.

\section{Conclusion}

\subsection{Design}

The verification of the models was a success for the single, double and triple pressure models. Results obtained from each software were in close agreement with each other which showed that the modelling methodology for each software was consistent. The results of the single and double pressure model were also consistent with that of V. Ganapathy from which the inputs for each were obtained and were, therefore, validated [11].

In order to validate the triple-pressure model, it was compared to plant data obtained from Alobaid et al. at design and off-design conditions [7]. The design model showed close agreement to that of the plant data with the exception of changes that had to be made. The changes made could not be avoided, which could have been due to the amount of assumptions that had to be made or a variation in gas composition which affects the calculation of gas enthalpy. Because of the complexity of the system, errors could not be easily pin pointed.

\subsection{Off-Design}

For the triple pressure model, the off-design case was able to be compared to plant data. The maximum error of the Virtual Plant model compared to plant data was $13 \%$ for off-design conditions. That of the Flownex model was $10 \%$. This is acceptable due to the fact that multiple assumptions had to be made while modelling the triple pressure system as well as the changes in design temperatures.

The results obtained show that Flownex is capable of modelling a combined-cycle power plant in design and off-design conditions.

\section{References}

[1] M. S. Y. Ebaid and Q. Z. Al-hamdan, "Thermodynamic Analysis of Different Configurations of Combined Cycle Power Plants, ” Mech. Eng. Res., vol. 5, no. 2, p. 89, (2015).

[2] M. P. Boyce, “Combined cycle power plants," Comb. Cycle Syst. Near-Zero Emiss. Power Gener., pp. 1-43, (2012).

[3] T. K. Ibrahim and M. M. Rahman, "Effect of Compression Ratio on Performance of Combined Cycle Gas Turbine, ” Int. J. Energy Eng., vol. 2, no. 1, pp. 9-14, (2012).

[4] V. Ganapathy, "Heat-recovery steam generators: Understand the basics, " Chem. Eng. Prog., vol. 92, no. 8, pp. 32-45, (1996).

[5] V. Ganapathy, Steam Generators and Waste Heat Boilers for Process and Plant Engineers. (2015).

[6] P. K. Nag, Power Plant Engineering. (2008).

[7] F. Alobaid, R. Starkloff, S. Pfeiffer, K. Karner, B. Epple, and H. Kim, “ $A$ comparative study of different dynamic process simulation codes for combined cycle power plants - Part A : Part loads and off-design operation," Fuel, vol. 153, pp. 692-706, (2015).

[8] A. Tica, H. Guéguen, D. Dumur, D. Faille, and F. Davelaar, "Design of a combined cycle power plant model for optimization," vol. 98, pp. 256-265, (2012). 
[9] M. Rauch, A. Galović, and Z. Virag, "Optimization of combined brayton-rankine cycle with respect to the total thermal efficiency," Trans. Famena, vol. 40, no. 1, pp. 1-10, (2016).

[10] T. Srinivas, A. V. S. S. K. S. Gupta, and B. V. Reddy, “Thermodynamic simulation of a combined cycle power plant at part-load operation, ” Cogener. Distrib. Gener. J., vol. 23, no. 4, pp. 50-63, (2008).

[11] V. Ganapathy, Industrial Boilers and Heat Recovery Steam Generators. CRC Press, (2002). 